\title{
In vitro antidiabetic potentials, antioxidant activities and phytochemical profile of african black pepper (Piper guineense)
}

\author{
L. A. Sulaimon ${ }^{1,2^{*}}$, E. O. Anise ${ }^{1}$, E. M. Obuotor ${ }^{3}$, T. A. Samuel ${ }^{2}$, A. I. Moshood ${ }^{1}$, M. Olajide ${ }^{1}$ and T. Fatoke ${ }^{2}$
}

\begin{abstract}
Background: Diabetes mellitus is a metabolic disorder of glucose metabolism and management of blood glucose level is the hallmark in the treatment of this disease. The present study investigated chemical composition, in vitro antioxidant and antidiabetic activity of different fractions of $80 \%$ methanol Piper guineense leaves extract.

Materials and methods: The crude methanolic extract of $P$. guineense was obtained following $80 \%$ methanol cold extraction and was successively partitioned with dichloromethane (DCM), ethyl acetate (EtOAc), n-butanol (nBuOH) and aqueous solvents to give four fractions. The chemical composition of the fractions from $P$. guineense was determined using gas chromatography coupled with mass spectrometry (GC-MS) and their potentials as antioxidant and anti-diabetes were evaluated.

Results: The percentage yields were 3.16, 2.22, 0.68 and $0.66 \%(\mathrm{w} / \mathrm{W})$ in $\mathrm{n}$-butanol, DCM, aqueous and ethyl acetate fractions of $P$. guineense methanolic extract, respectively. The GC-MS analyses identified a total of 71 and 34 phytochemicals in n-butanol and ethyl acetate fractions respectively. Tributyl acetylcitrate (10.95\%) and phytol (9.11\%) were the major components in the $n$-butanol fraction while ethyl piperonyl cyanoacetate $(27.35 \%)$ and phytol (15.17\%) were the major constituents in the ethyl acetate fraction. Ethyl acetate fraction had the highest ferric reducing antioxidant power with a value of $53.96 \pm 0.40 \mathrm{mgAAE} / \mathrm{g}$ while $\mathrm{n}$-butanol fraction possessed highest total antioxidant power $(9.98 \pm 0.15)$ followed by aqueous fraction $(9.72 \pm 0.02)$. The ethyl acetate and $n$-butanol fractions with $\mathrm{IC}_{50}$ value of $0.24 \pm 0.07$ and $0.83 \pm 0.15 \mu \mathrm{g} / \mathrm{mL}$ respectively elicited significant inhibitory activities against a-glucosidase while only $\mathrm{n}$-butanol fraction $\left(\mathrm{IC}_{50}=0.33 \pm 0.09 \mu \mathrm{g} / \mathrm{ml}\right)$ exhibited appreciable inhibition against a-amylase activity. However, none of the four fractions showed significant inhibitory activity towards dipeptidyl-peptidase-IV.
\end{abstract}

Conclusion: n-butanol and ethyl acetate fractions of $80 \%$ methanol $P$. guineense leaves extract can be a potential source of bioactive compounds of pharmacological importance in the management of diabetes.

Keywords: Piper guineense, Antioxidant, Anti-diabetic activity, Gas chromatography - mass spectrometry, Phytochemicals

\footnotetext{
* Correspondence: adlat4best@yahoo.com; sulaimon.lateef@cuab.edu.ng

'Department of Chemical Sciences, College of Natural and Applied Sciences,

Crescent University Abeokuta, Abeokuta, Ogun State, Nigeria

${ }^{2}$ Department of Biochemistry, Faculty of Basic Medical Sciences, College of

Medicine, University of Lagos, Lagos, Nigeria

Full list of author information is available at the end of the article
}

\section{Springer Open}

(c) The Author(s). 2020 Open Access This article is licensed under a Creative Commons Attribution 4.0 International License, which permits use, sharing, adaptation, distribution and reproduction in any medium or format, as long as you give appropriate credit to the original author(s) and the source, provide a link to the Creative Commons licence, and indicate if changes were made. The images or other third party material in this article are included in the article's Creative Commons licence, unless indicated otherwise in a credit line to the material. If material is not included in the article's Creative Commons licence and your intended use is not permitted by statutory regulation or exceeds the permitted use, you will need to obtain permission directly from the copyright holder. To view a copy of this licence, visit http://creativecommons.org/licenses/by/4.0/. 


\section{Highlights}

- The crude methanol extract of Piper guineense leaves was partitioned into dichloromethane (DCM), ethyl acetate (EtOAc), n-butanol $(\mathrm{nBuOH})$ and aqueous fractions

- Each fraction of Piper guineense was tested for antidiabetic and antioxidant activities

- The identification and quantification of phytochemicals in ethyl acetate and n-butanol fractions was based on GC-MS analysis

- The ethyl acetate and n-butanol fractions were potent inhibitor of $\alpha$-glucosidase while only n-butanol fraction exhibited appreciable inhibition against $\alpha$ amylase

- None of the four fractions showed significant inhibitory activity towards dipeptidyl-peptidase-IV.

- The n-butanol fraction showed the highest total antioxidant capacity while ethyl acetate fraction had the highest ferric reducing antioxidant power

- The GC-MS analysis identified a total of 71 and 34 phytochemicals in n-butanol and ethyl acetate fractions respectively

- Tributyl acetylcitrate (10.95\%) and phytol (9.11\%) were the major components in the n-butanol fraction while ethyl piperonyl cyanoacetate $(27.35 \%)$ and phytol (15.17\%) were the major constituents in the ethyl acetate fraction

\section{Introduction}

Diabetes mellitus is one of the major global public health problems of the twenty-first century affecting about 347 million people worldwide [1]. This problem is expected to double by the year 2030, if necessary actions were not taken [2]. This health disease is a chronic metabolic disorder caused by the total (or relative) defect of insulin, which is manifested clinically as elevated blood glucose. The diabetic patients exhibited a higher risk in the development of several chronic health complications including obesity, atherosclerosis, dyslipidemia and renal failure worldwide [3]. International Diabetes Federation [4] classified diabetes into clinical categories as: Type 1 Diabetes (T1DM), caused by $\beta$-cells destruction and usually leading to absolute insulin deficiency, Type 2 Diabetes (T2DM), due to progressive insulin secretory defect on the background of insulin resistance, and others such as gestational diabetes and specific type as monogenic diabetes syndromes, exocrine pancreas diseases, and drug or chemical induced diabetes.

In 2015, diabetes was one of the leading causes of non-communicable diseases (NCD) death, contributing 1.5 million deaths globally [5] and 321, 100 deaths [4] in the African region. The majority of people with diabetes are affected by Type 2 diabetes which is used to occur nearly entirely among adults, but now occurs in children too [6]. The high prevalence of Type 2 diabetes is as a result of aging, urbanization, and life styles changes [7]. The increasing prevalence of T2DM has stimulated the development of many new approaches to treat hyperglycemia in order to maintain glucose concentrations as close to normal as possible and to prevent the development of complications [8]. To date, many antidiabetic drugs of different classes and mechanisms of action are available as therapeutics for oral administration, including biguanides, sulfonylureas, meglitinides, PPAR- $\gamma$ agoinsts, $\alpha$-glucosidase inhibitors, DPP-4 inhibitors, SGLT2 inhibitors, dopamine-2 agonist; injectable therapies include GLP-1 agonists, amylin analogs, insulin and insulin analogues [9].

Despite the number of drugs available to control hyperglycemia and diabetes complication, there are concern regarding the side effects, availability and the cost of the drug in the middle- and low-income countries [10]. Hence, the research into other drugs that could better manage the treatment of diabetes is important and considering the invaluable biodiversity and countless number of metabolites present in plants have been a rich source in the search of new drugs [11]. Therefore, herbal prescriptions have received considerable attention as an alternative way to compensate for perceived deficiencies in orthodox pharmacotherapy [12].

Medicinal plants provide a potential source of hypoglycemic drugs because many plants and plant derived compounds have been used in the treatment of diabetes. Among these medicinal plants is Piper guineense, a West African spice plant from the family Piperaceae and genus piper. It is commonly called Ashanti pepper [13] and locally known as Uziza in Igbo, Masoro in Hausa and Iyere in Yoruba. Other common names are Benin pepper, Guinea pepper and false cubeb [13]. It is a perennial climbing plant that can grow up to $20 \mathrm{~m}$ tall by means of adventitious roots. It is widely consumed in Nigeria and Ghana on account of its nutritional and medicinal properties [14]. It is used in Western African cuisine because it contains piperine which imparts" heat" (piquantness) and a spicy pungent aroma to West African soup [13]. The proximate analysis of the plant revealed the presence of crude protein, fat, carbohydrate $[15,16]$, vitamins $\left(A, B_{1}, B_{2}, C\right.$ and $\left.E\right)$ [14-16] and minerals ( $\mathrm{Ca}, \mathrm{Mg}, \mathrm{K}, \mathrm{Na}, \mathrm{P}$ and $\mathrm{Fe}$ ) [14-16].

The phytochemical analysis of $P$. guineense leaves showed the presence of alkaloids (wisamine, dihydrowisamine, piperine and dihydropiperine) [17], saponins, tannins, flavonoids, resins [18], essential oil (dillapiol, elemicine, myristicine and safrole) [19] and hydrogen cyanides [20] which have a lot of pharmacological properties in diseases such as diabetes mellitus [21]. The components of essential oil exhibit bactericidal and 
antimicrobial effects on some micro-organisms [22] while large amount of beta-carophyllene in P. guineense has been investigated as an anti-inflammatory agent [23]. Similar to P. umbellatum, it is used in herbal medicine to treat rheumatism and arterial hypertension [24, 25]. Almost every part of the plant is used in forklore medicine to treat different diseases; for instance, the leaves are used to treat wounds, respiratory infections and syphilis [26], female infertility and low sperm count in male [27]. In China, P. guineense fruit extract is used in the treatment of epilepsy [28]. The seed is used as an adjuvant for the treatment of asthma [29] and weight control [30] while the root is used as chewing stick for healthy teeth [31].

$P$. guineense has been reported to be of value in the control of hyperglycemia in Type II diabetic Wistar rats $[32,33]$. However, it is pertinent to further investigate molecular targets of P. guineense in diabetes. Thus, the present study sought to evaluate the inhibitory effects of different fractions of $80 \%$ methanol extract of $P$. guineense leaves on carbohydrate hydrolyzing enzymes and to identify phytochemicals in different fractions of $P$. guineense leaves extract.

\section{Materials and methods}

\section{Chemicals and reagents}

Yeast $\alpha$-glucosidase, acarbose, p-nitrophenyl phosphate (pNPP), p-nitrophenyl $\alpha$-D-glucopyranoside (pNPG), Pro-4-nitroanilide, Ascorbic acid, 3, 5 - Dinitrosalicylic acid, Dipeptidyl petidase IV were purchased from Sigma-Aldrich (St. Louis, MO, USA). The other chemicals and reagents used were of analytical grade.

\section{Collection and identification of plant material}

The fresh leaves of Piper guineense were purchased from Lanfenwa Market, Abeokuta, Ogun State. The leaves were authenticated by Mr. A.S. Oyelakin (Plant Taxonomist) at the Herbarium of Department of Pure and Applied Botany, Federal University of Agriculture Abeokuta, Ogun State with voucher number FUNAAB A0061.

\section{Extraction and fractionation}

The leaves were washed, air dried for 7 days and grinded into fine powder with an electric blender. Fifty gram (50 $\mathrm{g}$ ) of the leaves was extracted with $250 \mathrm{ml}$ of $80 \%$ methanol for $24 \mathrm{~h}$. The methanol extract was then filtered with Whatman No.1 filter paper [34], the filtrate was concentrated under reduced pressure to remove methanol. Methanol was preferred because of its greater potential for extracting medicinal phytochemicals from their crude source [34]. The $80 \%$ methanol extract was then suspended in distilled water and then partition with ethyl-acetate (EtOAc), n-butanol (BuOH), Dichloromethane (DCM) and aqueous successively as previously described by Akinpelu et al., [35]. All the fractions were concentrated in rotary evaporator, air dried and stored in universal sample bottles [34, 35].

\section{In vitro a-amylase inhibitory assay}

This assay was conducted using the fraction of the sample as described using a modified procedure [36]. Test sample of $1 \mathrm{ml}$ in $0.02 \mathrm{M}$ sodium phosphate buffer $(\mathrm{pH}$ 6.9 with $0.006 \mathrm{M}$ Sodium chloride) containing $1 \mathrm{ml}$ of $\alpha$ amylase (from Aspergillus oryzae) were pre-incubated at $25^{\circ} \mathrm{C}$ for $30 \mathrm{~min}$, after which $1 \mathrm{ml}$ of $1 \%$ starch solution in $0.02 \mathrm{M}$ sodium phosphate buffer $(\mathrm{pH}$ 6.9) was added after incubation of the reaction mixture at $25^{\circ} \mathrm{C}$ for 10 min. The reaction was terminated by adding $1 \mathrm{ml}$ of 3 , 5- dinitrosalicylic acid (DNS) colour reagent $(1.0 \mathrm{~g}$ of DNS, $20 \mathrm{ml}$ of $2 \mathrm{M}$ of $\mathrm{NaOH}$ and $30 \mathrm{~g}$ of Sodium potassium tartarate in $100 \mathrm{ml}$ of distilled water). The sample test tubes were then incubated in boiling water for $5 \mathrm{~min}$ and cooled to room temperature. The reaction mixture was then diluted with $5 \mathrm{~mL}$ distilled water and the absorbance was measured at $540 \mathrm{~nm}$ using spectrophotometer. A control was prepared using the same procedure replacing the extract with distilled water. The generation of reducing sugar was quantified by reduction of 3,5dinitrosalicyclic acid to 3-amino-5-nitrosalicyclic acid. Acarbose was used as a positive control.

The $\alpha$-amylase inhibitory activity was calculated as percentage inhibition:

$$
\begin{aligned}
\% \text { Inhibition }= & {\left[\left(\mathrm{Abs}_{\mathrm{control}}-\mathrm{Abs}_{\text {fractions }}\right) / \mathrm{Abs}_{\mathrm{control}}\right] } \\
& \times 100
\end{aligned}
$$

Concentrations of fractions resulting in 50\% inhibition of enzyme activity $\left(\mathrm{IC}_{50}\right)$ were determined graphically.

\section{In vitro a-glucosidase inhibitory assay}

This assay was conducted using the fractions of $P$. guineense according to the method described by [37]. The substrate solution, p-nitrophenyl glucopyranoside (pNPG) was prepared in $20 \mathrm{mM}$ phosphate buffer, and $\mathrm{pH}$ 6.9. $20 \mu \mathrm{L}$ of $\alpha$-glucosidase $(0.2 \mathrm{U} / \mathrm{mL})$ was pre-incubated with $20 \mu \mathrm{L}$ of the different concentrations of the fractions for $10 \mathrm{~min}$. Then $20 \mu \mathrm{L}$ of $10.0 \mathrm{mM}$ (pNPG) as a substrate dissolved in $20 \mathrm{mM}$ phosphate buffer ( $\mathrm{pH}$ 6.9) was then added to start the reaction. The reaction mixture was incubated at $37^{\circ} \mathrm{C}$ for $15 \mathrm{~min}$ and stopped by adding $80 \mu \mathrm{L}$ of 0.2 $\mathrm{m}$ of $\mathrm{Na}_{2} \mathrm{CO}_{3}$. The $\alpha$-glucosidase activity was determined by measuring the yellow-colored paranitrophenol released from pNPG at $405 \mathrm{~nm}$ with microplate reader. Control contained the same reaction mixture and the same volume of phosphate was added instead of sample solution. Acarbose was dissolved in 10\% Dimethyl sulfoxide (DMSO) and used 
as a positive control. The inhibition percentage was calculated as follow;

$$
\begin{aligned}
\text { \%inhibition }= & \frac{[\text { Abs control }- \text { Abs sample }]}{[\text { Abs control }]} \\
& \times 100
\end{aligned}
$$

Concentrations of fractions resulting in 50\% inhibition of enzyme activity $\left(\mathrm{IC}_{50}\right)$ were determined graphically.

\section{In vitro dipeptidyl peptidase IV (DPP -IV) inhibitory assay} The assay was performed based on the method described by [38]. The assay was performed in micro well plates with 96 holes and read using a microplate reader. Vitagliptin as a standard of inhibitor DPP- IV was made in various concentrations $(5.0,2.5,1.25,0.625 \mathrm{mg} / \mathrm{dl})$ in a $50 \mathrm{mM}$ Tris $\mathrm{HCl}$ buffer ( $\mathrm{pH} 7.5)$, the volume used was $35 \mathrm{ul}$, The substrate was chromogenic GPPN $(0.2 \mathrm{mM}$ in Tris $\mathrm{HCl}$ buffer ( $\mathrm{pH} 7.5)$, cleaved by DPP-IV a serine protease that releases paranitroanlide (pNA) a yellow coloured product which is measured at $380 \mathrm{~nm}$. The enzyme solution of DPP-IV (0.05 units/ml) $15 \mathrm{ul}$ was added in micro well plates, and $35 \mathrm{ul}$ of the sample fraction with varying concentrations were then incubated for 15 min at $37^{\circ} \mathrm{C}$. Glacial acetic acid $25 \%$ (25ul) was added to the mixture to stop the enzymatic reaction; the absorbance was measured at $380 \mathrm{~nm}$ using the microplate reader. The total volume of the solution in the microwell plate is $125 \mathrm{ml}$. The results were then compared with negative control (without inhibitor). Tests were performed in triplicates. One unit of enzyme activity was defined as the amount of enzyme that catalyzed the release of $1 \mu \mathrm{mol}$ of pNA from the substrate per minute in the experimental conditions.

The percentage of inhibition was calculated using the following formula:

\%inhibition $=\frac{(\text { absorbance of control }- \text { absorbance of inhibitor })}{\text { Absorbance of control }} \times 100$

\section{Total antioxidant capacity}

The total antioxidant capacity was determined by phosphomolybdate method using ascorbic acid as standard [39]. An aliquot of $25 \mathrm{ul}$ of each $(1 \mathrm{mg} / \mathrm{ml})$ solution was mixed with $300 u$ ul of TAC reagent solution $(0.6 \mathrm{M}$ sulphuric acid, $28 \mathrm{mM}$ sodium phosphate and $4 \mathrm{mM}$ ammonium molybdate). The micro plate was incubated in a micro plate incubator for $90 \mathrm{~min}$. The absorbance of the mixtures was measured at $630 \mathrm{~nm}$ in a micro plate reader. The antioxidant activity of the extract was expressed as the number of mg equivalents to ascorbic acid (AAE)/g extract. All the experiments were carried out in triplicates.

\section{Ferric reducing antioxidant power}

The ferric reducing antioxidant power of the fractions was evaluated according to the method of [40]. An aliquot of $25 \mathrm{ul}$ of each extract $(1 \mathrm{mg} / \mathrm{dl})$ was mixed with 300ul of FRAP reagents $(300 \mathrm{mM}$ Acetate buffer, $0.03 \mathrm{~g}$ of TPTZ (2,4,6-Tris(2-pyridyl) 3- triazine) in $1 \mathrm{ml}$ of 40 $\mathrm{mM} \mathrm{HCL}$ and $18.6 \mathrm{ul}$ of $20 \mathrm{mM}$ ferric chloride in $5 \mathrm{ml}$ of water in ratio 10:1:1). After incubation for $90 \mathrm{~min}$ at $37^{\circ} \mathrm{C}$, the absorbance was measured at $593 \mathrm{~nm}$ in a micro plate reader. The assay was carried out in triplicates. And the antioxidant activity of the extract was expressed as the number of mg equivalents of ascorbic acid (AAE)/g extract.

\section{Gas chromatography - mass spectrometry (GC-MS) analysis}

The leaves fractions were subjected to GC-MS analysis carried out at the Federal Institute of Industrial Research, Oshodi (FIIRO), Lagos State, Nigeria. This method was used for the identification of biologically active natural chemical constituents [41]. It was carried out by using GC-MS-5975C Agilent system composed of an auto sampler and a gas chromatograph interfaced with a mass spectrometer (GC-MS) instrument. It was worked with the following conditions using a fitted variant column Agilent JSW HP- 5 MS $(30 \mathrm{~m} \times 0.32 \mathrm{~mm} \times$ $0.25 \mu \mathrm{M})$, sample was dissolved in hexane and $1 \mu \mathrm{L}$ inject automatically into the column with the injector temperature set at $250{ }^{\circ} \mathrm{C}$. Helium gas was used as the carrier gas at a flow rate of $1 \mathrm{ml} / \mathrm{min}$. GC oven temperature was started at $50^{\circ} \mathrm{C}$ held for 5 mins and then raised to $80^{\circ} \mathrm{C}$ at the rate of $5^{\circ} \mathrm{C} / \min$ for $9 \mathrm{~min}$. The temperature of injector and ion source were maintained at $250{ }^{\circ} \mathrm{C}$ and $280^{\circ} \mathrm{C}$ respectively. For the GC-MS analysis an injector was done on a duplicate of the same operational conditions. The mass spectrum of compounds in sample was obtained by electron ionization at $7 \mathrm{eV}$, ion source temperature was $230^{\circ} \mathrm{C}$ and interface temperature $250^{\circ} \mathrm{C}$ and its detector was operated in scan mode from 45 to $450 \mathrm{amu}$ (atomic mass units). A scan interval of $0.5 \mathrm{~s}$ and fragment from 45 to $450 \mathrm{amu}$ was maintained. The total running time was 60 mins.

\section{Identification of chemical constituents}

The chemical compounds were identified by comparing the spectral data obtained on the Gas Chromatograph Mass Spectroscopy with the data base of National Institute Standard and Technology Library and that of Wiley GC-MS library and confirmed by comparison of their retention indices measured index (Ki) to a homologous series of n-alkanes. The name of the chemical component, molecular weight and the chemical structure of the fraction of the leaves of Piper guineense were identified. 


\section{Statistical analysis}

All the assays were done in triplicate. Means, Standard Error of Means (SEM) and $\mathrm{IC}_{50}$ values were calculated using a Microsoft excel program and Graph $\mathrm{Pad}^{\odot}$ prism 6.0. The test of significance was done using Student's ttest (two-tailed). Replicate values for each treatment were compared with replicate values of the control; and values considered significant at $\mathrm{p}^{<} 0.05$.

\section{Results}

Percentage yield of different solvent fractions of $P$. guineense

The percentage yield of the different solvent fraction is as shown in Table 1. The highest yield was obtianed from the n-butanol fraction which gave value of $3.16 \%$. This was followed by the DCM fraction with a yield of $2.22 \%$. the aqueous fraction showed a yield of $0.68 \%$ while the least yield was obtained with the ethyl acetate fraction $(0.66 \%)$.

The in vitro inhibitory effect of solvent fractions of $P$. guineense on a-amylase

The in vitro inhibitory effect of the solvent fractions from the $80 \%$ methanol leaf extract of $P$. guineense towards $\alpha$-amylase activity is as shown in Table 2 . The result indicated that the $\mathrm{n}-\mathrm{BuOH}$ fraction exhibited a significant $\left(\mathrm{p}^{<0.05)}\right.$ inhibition on the $\alpha$-amylase activity with an $\mathrm{IC}_{50}$ value of $0.33 \pm 0.09$ as compared to acarbose that elicited an inhibitory activity of $1.09 \pm 0.19 \mu \mathrm{g} /$ $\mathrm{ml}$. The other fractions exhibited activity significantly $\left(p^{<} 0.05\right)$ lower than acarbose.

The a-glucosidase inhibitory effect of solvent fractions of P. guineense

The in vitro inhibitory effect of the solvent test fractions on the activity of $\alpha$-glucosidase is as shown in Table 3. The highest inhibitory effect towards $\alpha$-glucosidase was observed with the ethyl acetate fraction with an $\mathrm{IC}_{50}$ of $0.24 \pm 0.07 \mu \mathrm{g} / \mathrm{ml}$. This was followed by $\mathrm{n}$-butanol with an $\mathrm{IC}_{50}$ of $0.83 \pm 0.15$. The $\mathrm{IC}_{50}$ values of ethyl acetate and n-butanol fractions were significantly ( $\mathrm{p}^{<0.05)}$ lower than acarbose, the positive standard, which elicited an $\mathrm{IC}_{50}$ value of $1.46 \pm 0.21 \mu \mathrm{g} / \mathrm{ml}$. The DCM and aqueous fractions showed weak effect on $\alpha$-glucosidase while it

Table 1 Percentage yield of different solvent fractions of $80 \%$ methanol extract of $P$. guineense

\begin{tabular}{ll}
\hline Solvent fraction & Yield (\%) \\
\hline n-butanol (n-BuOH) & 3.16 \\
Dichloromethane (DCM) & 2.22 \\
Aqueous & 0.68 \\
Ethyl acetate (EtOAc) & 0.66 \\
\hline
\end{tabular}

could be observed that ethyl acetate and n-BuOH fractions were more effective than the positive standard.

\section{The in vitro DPP-IV inhibition of DPP-IV by solvent fractions of $P$. guineense}

The result of the inhibitory effects of the different solvent fractions of P.guineense on dipeptidyl peptidase -IV activity is as shown in Table 4. It was observed that none of the fractions elicited any significant activity when compared to the positive standard (vidagliptin) used as control which gave an $\mathrm{IC}_{50}$ value of $0.07 \pm 0.01 \mu \mathrm{g} / \mathrm{ml}$.

\section{Ferric reducing antioxidant power (FRAP) of different solvent fractions of $P$. guineense}

The result of the ferric reducing antioxidant power (FRAP) of the four solvent fractions obtained from the $80 \%$ methanol extract is as shown in Table 5. It was observed that the ethyl acetate fraction elicited the highest antioxidant power with a value of $53.96 \pm 3.40 \mathrm{mg} \mathrm{AAE} /$ $\mathrm{g}$ followed by the dichloromethane fraction (DCM) fraction with a value of $47.52 \pm 0.63 \mathrm{mg} \mathrm{AAE} / \mathrm{g}$ of $P$. guineense while the least FRAP activity was observed for the aqueous fraction with a value of $16.98 \pm 2.10 \mathrm{AAE} / \mathrm{g}$.

\section{Total antioxidant capacity (TAC) of different solvent fractions of $P$. guineense}

The result of the Total antioxidant capacity of the four solvent fractions obtained from the $80 \%$ methanol extract is as shown in Table 6. It was observed that the nbutanol fraction exhibited the highest total antioxidant capacity of $9.98 \pm 0.15 \mathrm{mg} \mathrm{AAE} / \mathrm{g}$ of P.guineense while the least TAC activity was observed for dichloromethane fraction with a value of $6.19 \pm 0.10 \mathrm{AAE} / \mathrm{g}$.

\section{Chemical composition of the $n$-butanol fraction of $P$. guineense}

The analysis by GC-MS of the n-butanol fraction obtained from the $80 \%$ methanol extract of $P$. guineense is as shown in Table 7. The analysis showed that Seventyone (71) compounds were detected in the n-butanol fraction. The compound tributyl acetylcitrate with a composition of $10.95 \%$ was the major constituent. This was followed by phytol with a composition of $9.11 \%$ and 9,10-Dimethyltricyclo [4.2.1.1(2,5)] decane with a composition of $6.74 \%$. Other compounds identified with compositions above $2 \%$ include; 2-Butenal, 2-methyl-4(2,6,6-trimethyl-1-, (2.88\%), 1-Cyclohexane-1-methanol alpha,2,6,6, (4.26\%), 3-Buten-2-one, 4-(4-hydroxy-2,6,6trimethyl (4.26\%), dibutyl phthalate $(3.48 \%)$, hexanedecanoic acid (3.09\%). All the other compounds had compositions that were less than $2 \%$. 
Table 2 In vitro inhibitory aactivities of different solvent fractions of $P$. guineense on a amylase

\begin{tabular}{|c|c|c|c|}
\hline Fraction & Concentration $(\mu \mathrm{g} / \mathrm{ml})$ & $\%$ Inhibition \pm SEM & $\mathrm{IC}_{50}(\mu \mathrm{g} / \mathrm{ml}) \pm \mathrm{SEM}$ \\
\hline \multirow[t]{6}{*}{ AQUEOUS } & 5.00 & $54.00 \pm 1.22$ & $2.10 \pm 0.10$ \\
\hline & 2.50 & $50.96 \pm 2.17$ & \\
\hline & 1.25 & $45.46 \pm 0.44$ & \\
\hline & 0.625 & $33.50 \pm 3.04$ & \\
\hline & 0.3125 & $22.45 \pm 4.13$ & \\
\hline & 0.15625 & $15.11 \pm 4.12$ & \\
\hline \multirow[t]{6}{*}{ BUTANOL } & 5.00 & $76.63 \pm 0.23$ & $0.33 \pm 0.09$ \\
\hline & 2.50 & $72.07 \pm 2.02$ & \\
\hline & 1.25 & $63.27 \pm 0.86$ & \\
\hline & 0.625 & $55.13 \pm 2.13$ & \\
\hline & 0.3125 & $52.44 \pm 1.84$ & \\
\hline & 0.15625 & $41.94 \pm 0.51$ & \\
\hline \multirow[t]{6}{*}{ DCM } & 5.00 & $42.25 \pm 3.7$ & $5.75 \pm 0.63$ \\
\hline & 2.50 & $36.73 \pm 1.67$ & \\
\hline & 1.25 & $17.83 \pm 0.09$ & \\
\hline & 0.625 & $17.21 \pm 0.25$ & \\
\hline & 0.3125 & $16.60 \pm 0.09$ & \\
\hline & 0.15625 & $5.27 \pm 4.50$ & \\
\hline \multirow[t]{6}{*}{ ETHYLACETATE } & 5.00 & $39.30 \pm 1.42$ & $6.70 \pm 0.19$ \\
\hline & 2.50 & $29.64 \pm 2.98$ & \\
\hline & 1.25 & $22.52 \pm 1.88$ & \\
\hline & 0.625 & $17.89 \pm 3.81$ & \\
\hline & 0.3125 & $11.58 \pm 3.81$ & \\
\hline & 0.15625 & $10.61 \pm 4.40$ & \\
\hline \multirow[t]{6}{*}{ ACARBOSE } & 5.00 & $91.33 \pm 022$ & $1.09 \pm 0.19$ \\
\hline & 2.50 & $89.43 \pm 0.38$ & \\
\hline & 1.25 & $75.07 \pm 1.73$ & \\
\hline & 0.625 & $62.06 \pm 4.03$ & \\
\hline & 0.3125 & $30.08 \pm 4.51$ & \\
\hline & 0.15625 & $27.01 \pm 0.21$ & \\
\hline
\end{tabular}

\section{Chemical composition of the ethyl acetate fraction of $P$. guineense}

Analysis of the ethyl acetate fraction obtained from the $80 \%$ methanol extract of $P$. guineense by GC-MS is as shown in Table 8 . The analysis shows that thirty-four (34) compounds were detected in the ethyl acetate fraction. Ethyl piperonyl cyanoacetate and phytol were identified as the major compounds in the fraction with percentage compositions of 27.35 and $15.17 \%$ respectively. Other constituents include piperine (5.36\%), benzene 3-iodo-1-methoxy-1 methylpropyl (8.65\%),(R)(-)-14-Methyl-8-hexadecyn-1-ol (6.88\%), Octacosane (4.08\%). All the other compounds had compositions that were less than $2 \%$.

\section{Discussion}

Considering the severity of diabetes and its complications, any new therapeutic innovation is of interest to prevent deleterious effects of hyperglycemia. Antidiabetics agent from natural sources is vital research most especially considering the side effects and high cost of most of the available synthetic drugs. In this study, different soluble fractions of $P$. guineense were investigated against $\alpha$-amylase, $\alpha$-glucosidase and DPP-IV activities inhibitory assay. The $P$. guineense leaves were fractionated into Aqueous, Butanol $(\mathrm{BuOH})$, ethyl acetate (EtOAc), dichloromethane (DCM) and the percentage yield were $0.68,3.16,0.66$ and 2.22 respectively. The difference in polarities of the partition solvents might 
Table 3 In vitro inhibitory effects of different solvent fractions fractions of $P$. guineense on a- glucosidase activity

\begin{tabular}{|c|c|c|c|}
\hline Fraction & Concentration $(\mathrm{mg} / \mathrm{ml})$ & $\%$ Inhibition \pm SEM & $\mathrm{IC} C_{50}(\mathrm{mg} / \mathrm{ml}) \pm \mathrm{SEM}$ \\
\hline \multirow[t]{6}{*}{ AQUEOUS } & 5.00 & $69.91 \pm 0.01$ & $2.90 \pm 0.43$ \\
\hline & 2.50 & $61.44 \pm 0.40$ & \\
\hline & 1.25 & $54.77 \pm 0.30$ & \\
\hline & 0.625 & $52.97 \pm 0.20$ & \\
\hline & 0.3125 & $21.98 \pm 0.68$ & \\
\hline & 0.15625 & $17.66 \pm 0.67$ & \\
\hline \multirow[t]{6}{*}{ BUTANOL } & 5.00 & $62.33 \pm 2.06$ & $0.83 \pm 0.15$ \\
\hline & 2.50 & $58.90 \pm 2.96$ & \\
\hline & 1.25 & $57.10 \pm 2.84$ & \\
\hline & 0.625 & $51.66 \pm 6.30$ & \\
\hline & 0.3125 & $36.34 \pm 7.25$ & \\
\hline & 0.15625 & $21.77 \pm 3.36$ & \\
\hline \multirow[t]{6}{*}{ DCM } & 5.00 & $70.30 \pm 2.57$ & $1.91 \pm 0.03$ \\
\hline & 2.50 & $56.91 \pm 3.35$ & \\
\hline & 1.25 & $54.94 \pm 2.47$ & \\
\hline & 0.625 & $47.23 \pm 2.47$ & \\
\hline & 0.3125 & $30.80 \pm 1.03$ & \\
\hline & 0.15625 & $27.03 \pm 0.10$ & \\
\hline \multirow[t]{6}{*}{ ETHYLACETATE } & 5.00 & $82.32 \pm 2.87$ & $0.24 \pm 0.07$ \\
\hline & 2.50 & $74.19 \pm 3.56$ & \\
\hline & 1.25 & $63.06 \pm 0.27$ & \\
\hline & 0.625 & $61.80 \pm 0.66$ & \\
\hline & 0.3125 & $56.75 \pm 0.93$ & \\
\hline & 0.15625 & $40.53 \pm 1.25$ & \\
\hline \multirow[t]{6}{*}{ ACARBOSE } & 5.00 & $23.81 \pm 1.15$ & $1.46 \pm 0.21$ \\
\hline & 2.50 & $22.08 \pm 0.75$ & \\
\hline & 1.25 & $20.35 \pm 0.43$ & \\
\hline & 0.625 & $17.75 \pm 0.43$ & \\
\hline & 0.3125 & $12.55 \pm 0.12$ & \\
\hline & 0.15625 & $10.02 \pm 0.07$ & \\
\hline
\end{tabular}

influence the solubility of the chemical constituents of the sample and its extraction yield; this might be the reason for the variation in percentage yield.

One of the therapeutic approaches for treating type II diabetes is to decrease postprandial hyperglycemia and mainly two carbohydrate hydrolyzing enzymes ( $\alpha$-amylase and $\alpha$-glucosidase) are responsible for postprandial hyperglycemia. The enzyme, $\alpha$-amylase, begins the process of carbohydrate digestion by hydrolyzing of 1, 4glycosidic linkages of polysaccharides (starch, glycogen) to disaccharides and $\alpha$-glucosidase catalyze the disaccharides to monosaccharide, which leads to postprandial hyperglycemia [42]. Hence, inhibitors of the carbohydrate hydrolyzing enzymes are useful in the control of hyperglycemia as they delay the carbohydrate digestion but do not prevent the absorption of ingested carbohydrates, reducing the postprandial glucose and insulin peak. Thus, the inhibitory effect of different fractions of Piper guineense on the carbohydrate hydrolyzing enzymes were investigated, all the fractions showed different level of inhibitory activities against $\alpha$-amylase enzyme over the range of $0.15626-5 \mathrm{mg} / \mathrm{ml}$ and $\mathrm{IC}_{50}$ (fraction concentration that inhibits the $50 \%$ enzyme activity) values of $2.10,0.33,5.75,6.70 \mathrm{mg} / \mathrm{ml}$ were obtained for aqueous, $\mathrm{BuOH}$, EtOAc, DCM and EtOAc fractions, respectively. $\mathrm{BuOH}$ fraction had the strongest activities compared to others and its percentage inhibition increase as concentration increases (concentration dependent). The $\mathrm{BuOH}$ fraction showed three times more potent $\alpha$-amylase inhibitory activity than the acarbose, a commercially used $\alpha$-glucosidase inhibitor that has $\mathrm{IC}_{50}$ value of $1.09 \mathrm{mg} / \mathrm{ml}$. 
Table 4 In vitro inhibitory effects of different solvent fractions of P.guineense on the activity of dipeptidyl peptidase -IV (DPP-IV)

\begin{tabular}{|c|c|c|c|}
\hline Fraction & Concentration $(\mathrm{mg} / \mathrm{ml})$ & $\%$ Inhibition \pm SEM & $\mathrm{IC}_{50}(\mathrm{mg} / \mathrm{ml}) \pm \mathrm{SEM}$ \\
\hline \multirow[t]{6}{*}{ AQUEOUS } & 5.00 & $49.06 \pm 0.40$ & $4.60 \pm 0.87$ \\
\hline & 2.50 & $45.28 \pm 1.47$ & \\
\hline & 1.25 & $35.85 \pm 1.08$ & \\
\hline & 0.625 & $20.75 \pm 0.29$ & \\
\hline & 0.3125 & $4.72 \pm 0.18$ & \\
\hline & 0.15625 & $1.52 \pm 0.10$ & \\
\hline \multirow[t]{6}{*}{ BUTANOL } & 5.00 & $54.38 \pm 0.10$ & $3.22 \pm 0.03$ \\
\hline & 2.50 & $49.70 \pm 2.56$ & \\
\hline & 1.25 & $40.75 \pm 0.18$ & \\
\hline & 0.625 & $35.36 \pm 0.96$ & \\
\hline & 0.3125 & $17.54 \pm 0.28$ & \\
\hline & 0.15625 & $4.65 \pm 0.10$ & \\
\hline \multirow[t]{6}{*}{ DCM } & 5.00 & $73.70 \pm 2.50$ & $1.83 \pm 0.35$ \\
\hline & 2.50 & $50.96 \pm 1.80$ & \\
\hline & 1.25 & $48.49 \pm 1.09$ & \\
\hline & 0.625 & $48.19 \pm 0.06$ & \\
\hline & 0.3125 & $45.12 \pm 0.20$ & \\
\hline & 0.15625 & $10.38 \pm 1.40$ & \\
\hline \multirow[t]{6}{*}{ ETHYL ACETATE } & 5.00 & $58.50 \pm 0.05$ & $1.45 \pm 0.12$ \\
\hline & 2.50 & $55.35 \pm 0.40$ & \\
\hline & 1.25 & $51.05 \pm 0.38$ & \\
\hline & 0.625 & $46.02 \pm 0.20$ & \\
\hline & 0.3125 & $43.31 \pm 0.60$ & \\
\hline & 0.15625 & $18.67 \pm 0.84$ & \\
\hline \multirow[t]{6}{*}{ VIDAGLIPTIN } & 5.00 & $8.95 \pm 0.10$ & $0.07 \pm 0.01$ \\
\hline & 2.50 & $16.09 \pm 3.20$ & \\
\hline & 1.25 & $38.50 \pm 0.20$ & \\
\hline & 0.625 & $48.60 \pm 2.55$ & \\
\hline & 0.3125 & $60.50 \pm 1.08$ & \\
\hline & 0.15625 & $69.05 \pm 0.20$ & \\
\hline
\end{tabular}

Moreover, the fractions showed different inhibitory activities against the $\alpha$-glucosidase enzyme with the $\mathrm{IC}_{50}$ values of $2.90,0.83,1.91$ and $0.24 \mathrm{mg} / \mathrm{ml}$ for aqueous, $\mathrm{BuOH}, \mathrm{DCM}$ and EtAOc respectively. The EtAOc fractions showed six times more potent $\alpha$-glucosidase inhibitory activity, while $\mathrm{BuOH}$ fraction showed two times inhibitory activity compare to the acarbose. The difference in strong inhibitory activities of $\mathrm{BuOH}$ and EtAOc fractions was resulted from the differential distributions of the active compounds in the fractions.

Preventing the degradation of incretin hormones by DPP-IV inhibition became the attractive therapeutic
Table 5 Ferric reducing antioxidant power (FRAP) activities of different solvent fractions of $P$. guineense

\begin{tabular}{ll}
\hline SAMPLE/ FRACTION & Mean $(\mathbf{m g ~ A A E} / \mathbf{g}) \pm$ SEM \\
\hline Aqueous & $16.98 \pm 0.06$ \\
Butanol & $33.47 \pm 0.79$ \\
Ethylacetate & $53.96 \pm 0.40$ \\
Dicholoromethane & $47.52 \pm 0.63$ \\
\hline
\end{tabular}

Table 6 Total antioxidant capacity (TAC) activities of different solvent fractions of $P$. guineense

\begin{tabular}{ll}
\hline Sample/ fractions & Mean \pm SEM $(\mathbf{m g ~ A A E} / \mathbf{g})$ \\
\hline Aqueous & $9.72 \pm 0.02$ \\
Butanol & $9.98 \pm 0.15$ \\
Ethylacetate & $7.68 \pm 0.17$ \\
Dicholoromethane & $6.19 \pm 0.10$ \\
\hline
\end{tabular}


Table 7 Chemical composition of the n-butanol fraction of $P$. guineense following GC-MS analysis

\begin{tabular}{|c|c|c|c|}
\hline Peak & Retention Time & Area \% & Name \\
\hline 1 & 4.794 & 0.34 & Pentanoic acid, 3-methyl-4-oxo- \\
\hline 2 & 7.04 & 0.41 & Phenol \\
\hline 3 & 7.300 & 0.48 & But-3-enul (E)-2methyl-2-enoate \\
\hline 4 & 7.826 & 0.25 & Benzylamine, N-(3-chloro-2,2-dimethyl-1p) \\
\hline 5 & 8.184 & 0.28 & p-Cresol \\
\hline 6 & 8.354 & 0.88 & Phenol, 2-methoxy- \\
\hline 7 & 8.450 & 0.25 & Cyclohexane, 1-propenyl- \\
\hline 8 & 9.283 & 0.19 & Phenol, 3,4-dimethyl \\
\hline 9 & 9.575 & 0.21 & Phenol, 3.4-dimethyl \\
\hline 10 & 9.674 & 0.20 & 1,2-Benzenediol, o-valeryl- \\
\hline 11 & 9.862 & 1.99 & Benzofuran, 2,3-dihydro- \\
\hline 12 & 9.998 & 0.30 & 1H-Pyrrole-2,5-dione, 3-ethyl-4-methyl- \\
\hline 13 & 10.124 & 0.27 & 2-Coumaranone \\
\hline 14 & 10.271 & 0.06 & Ethosuximide \\
\hline 15 & 10.311 & 0.08 & Methyl 5-norbornene-2-carboxylate \\
\hline 16 & 10.631 & 0.36 & 2(1H)-Naphthalenone, 3,4,4a,5,6,7-hexahy \\
\hline 17 & 10.793 & 1.66 & Indole \\
\hline 18 & 10.897 & 1.97 & 2-Methoxy-4-vinylphenol \\
\hline 19 & 10.973 & 0.37 & 1-Heptanol, 2-propyl- \\
\hline 20 & 11.090 & 0.11 & 2,2,3,3-Tetrathyloxirane \\
\hline 21 & 11.246 & 0.77 & 1,4-Butanediol, 2,3-bis(methylene)- \\
\hline 22 & 11.559 & 0.34 & 1-Dodecene \\
\hline 23 & 11.631 & 0.13 & Oxalic acid, allyl nonyl ester \\
\hline 24 & 11.827 & 0.46 & Vanillin \\
\hline 25 & 11.888 & 0.20 & 6,8-Nonadien-2-one, 6-methyl-5-(1-methyl \\
\hline 26 & 11.951 & 0.15 & 6,8-Nonadien-2-one, 6-methyl-5-(1-methyl \\
\hline 27 & 12.098 & 0.66 & 6,8-Nonadien-2-one, 6-methyl-5-(1-methyl \\
\hline 28 & 12.284 & 0.20 & Phenol, 2-methyoxy-4-(1-propenyl)-, (Z)- \\
\hline 29 & 12.388 & 0.24 & 1b5,5,6a-Tetramethyl-octahydro-1-oxa- \\
\hline 30 & 12.542 & 0.44 & 2-Methyl-4-(2,6,6-trimethylcyclohex-1-enyl \\
\hline 31 & 12.661 & 0.27 & 5-Hepten-3-yn-2-ol,6-methyl-5-(1-methyle \\
\hline 32 & 12.899 & 0.28 & 2-Heptenal, 2-propyl- \\
\hline 33 & 12.996 & 0.46 & 2-Hydroxl-3,5,5-trimethyl-cyclohex-2-enor \\
\hline 34 & 13.077 & 0.49 & 4H-1,3,2-Dioxaborin, 6-ethenyl-2-ethyl-4- \\
\hline 35 & 13.133 & 0.67 & 5-Ethenyl-5-(1-methyl-3-butenyl)hexahydro \\
\hline 36 & 13.242 & 0.19 & 2(4H)-Benzofuranone,5,6,7,7a-tetrahydro \\
\hline 37 & 13.298 & 0.20 & 4'Ethoxy-2'hydroxyoctadecanophenone \\
\hline 38 & 13.440 & 0.47 & E-14-Hexadecenal \\
\hline 39 & 13.599 & 0.14 & Cyclopentanone, 2-(2-nitro-2-heptenyl) \\
\hline 40 & 13.706 & 0.17 & 3-Hexen-2-one, 3-cyclohexyl-4-ethyl \\
\hline 41 & 13.819 & 0.29 & cis-Z-alpha-Bisbolene epoxide \\
\hline 42 & 13.967 & 1.02 & trans-p-Mentha-2,8-dienol \\
\hline 43 & 14.102 & 1.70 & 2-Cyclohexen-1-one, 4-(3-hydroxy-1-buten \\
\hline 44 & 14.144 & 0.41 & 11-Isopropylidene-tricyclo[ $[4,3,1,1(2,5)$ und \\
\hline
\end{tabular}


Table 7 Chemical composition of the n-butanol fraction of P. guineense following GC-MS analysis (Continued)

\begin{tabular}{|c|c|c|c|}
\hline Peak & Retention Time & Area \% & Name \\
\hline 45 & 14.204 & 1.37 & 6-epi-shyobunol \\
\hline 46 & 14.297 & 2.05 & 3-Buten-2-one, 4-(2-hydroxy-2,6,6-trimethyl \\
\hline 47 & 14.444 & 3.35 & 3-Buten-2-one, 4-(4-hydroxy-2,6,6-trimethyl \\
\hline 48 & 14.631 & 0.90 & 2-Cyclohexen-1-one, 4-(3-hydroxybutyl)-3 \\
\hline 49 & 14.893 & 0.85 & 4-((1E)-3-Hydroxy-1-propenyl)-2-methoxy \\
\hline 50 & 15.107 & 1.94 & 2H-Pyran, 2-(2-heptadecynyloxy) tetrahydro \\
\hline 51 & 15.167 & 1.45 & 1H-Indole, 3-(3,7,11,15-tetramethylhexade \\
\hline 52 & 15.266 & 2.88 & 2-Butenal, 2-methyl-4-(2,6,6-trimethyl-1- \\
\hline 53 & 15.309 & 6.74 & 9,10-Dimethyltricyclo [4.2.1.1 (2,5)]decane \\
\hline 54 & 15.487 & 1.50 & Spiro $[4,5]$ decan-7-one. 1,8-dimethyl-8,9 \\
\hline 55 & 15.626 & 4.26 & 1-Cyclohexane-1-methanol alpha,2,6,6 \\
\hline 56 & 15.775 & 1.43 & Acetic acid, 10,11-dihydroxy-3,7,11trimethy \\
\hline 57 & 16.110 & 2.66 & Hexadecanoicaci, methyl ester \\
\hline 58 & 16.451 & 3.48 & Dibutyl phthalate \\
\hline 59 & 16.570 & 2.99 & 1,2-Benzenedicarboxylic acid, butyl octyl \\
\hline 60 & 17.071 & 1.37 & 9,9-Dimethoxybicyclo[3,3,1]nona-2,4- \\
\hline 61 & 17.124 & 1.85 & Phthalic acid, isobutyl octadecyl ester \\
\hline 62 & 17.281 & 1.39 & 2-Dodecen-1yl (-) succinic anhydride \\
\hline 63 & 17.339 & 2.18 & Cyclopropaneoctanoic acid, 2- \\
\hline 64 & 17.391 & 2.36 & 9,12,15-Octadecatrienoic acid ethyl ester \\
\hline 65 & 17.466 & 9.11 & Phytol \\
\hline 66 & 17.710 & 2.66 & Butane,1-(2,2-dichloro-3,3-dimethylcyclop \\
\hline 67 & 17.822 & 2.05 & Decanediocacid,dibutyl ester \\
\hline 68 & 18.322 & 10.95 & Tributyl acetylcitrate \\
\hline 69 & 18.652 & 2.11 & 1b,4a-Epoxy-2H-cyclopenta \\
\hline 70 & 20.311 & 3.09 & Hexandecanoic acid \\
\hline 71 & 20.466 & 2.01 & Bis(2-ethylhexyl)phthalate \\
\hline
\end{tabular}

strategy because several DPP-IV inhibitors have consistently reduced blood glucose predominately postprandial and this appears to be associated with increases in active circulating GLP-1 [43]. The mechanism of DPP-IV inhibitors is to increase incretin level (GLP-1 and GIP), which inhibit glucagon release, which in turn increases insulin secretion, decreases gastric emptying [44]. In the DPP-IV inhibitory assay, all the fractions showed concentration dependent inhibition (the \% inhibition increases as the concentration increases) activities against DPP-IV over the range of $0.15625-5 \mathrm{mg} / \mathrm{ml}$ with $\mathrm{IC}_{50}$ values of $4.60 \pm 0.87,3.22 \pm 0.03,1.83 \pm 0.35,1.45 \pm 0.12$ $\mathrm{mg} / \mathrm{mL}$ obtained for Aqueous, $\mathrm{BuOH}, \mathrm{DCM}$ and EtOAc respectively. The EtOAc fraction was the most potent among the fractions with moderate activity against the DPP-IV. The action of EtOAc fraction showed that it has the ability to protect the incretin from degradation by the DPP-IV to metabolites that are devoid of insulin releasing activity.

Fe (III) reduction is often used as an indicator of electron donating activity, which is an important mechanism of phenolic antioxidant action $[45,46]$. The reducing power ability (FRAP) of a compound generally depends on the presence of the reductones (antioxidants), which exert the antioxidant activity by breaking the free radical chain by donating a hydrogen atom [47]. Table 4 depicts the reductive capabilities of various fractions of Piper guineense. The FRAP activities showed that the reducing power ability of the fraction decreased in the order EtAOc > DCM $>\mathrm{BuOH}>\mathrm{AQUEOUS}$ with value of $53.96 \pm 0.40,47.52 \pm 0.63,33.47 \pm 0.79$ and $16.98 \pm 0.06$ mgAAE/g \pm SEM respectively. The antioxidant present in the fraction caused reduction of $\mathrm{Fe}^{3+} /$ ferricyanide complex to the ferrous form and thus proved the 
Table 8 Chemical composition of the ethyl acetate fraction of P. guineense following GC-MS analysis

\begin{tabular}{|c|c|c|c|}
\hline Peak & R. Time & Area\% & Name \\
\hline 1 & 4.895 & 0.18 & Pentanoic acid, 3-methyl-4-oxo- \\
\hline 2 & 6.038 & 0.03 & Cyclohexanone \\
\hline 3 & 6.985 & 0.39 & Ethane, 1,1,1-triethoxy- \\
\hline 4 & 9.421 & 0.03 & Cyclopentane, 1,1,3-trimethyl- \\
\hline 5 & 9.864 & 0.85 & Benzofuran, 2,3-dihydro- \\
\hline 6 & 610.125 & 0.12 & 2-Coumaranone \\
\hline 7 & 10.613 & 0.05 & 2-Isopropyl-5-methylphenyl 2-methylbutano \\
\hline 8 & 10.899 & 1.07 & 4-Hydroxy-2-methylacetophenone \\
\hline 9 & 11.159 & 1.80 & 3-Amino-4-piperonyl-5-pyrazolone \\
\hline 10 & 11.290 & 1.95 & 1,6-Anhydro-4-(3,4-methylenedioxyphenylm \\
\hline 11 & 11.377 & 1.59 & 3-Amino-4-piperonyl-5-pyrazolone \\
\hline 12 & 11.558 & 0.11 & 1-Tetradecene \\
\hline 13 & 12.764 & 27.35 & Ethyl piperonyl cyanoacetate \\
\hline 14 & 13.439 & 0.39 & Cetene \\
\hline 15 & 15.316 & 6.88 & (R)-(-)-14-Methyl-8-hexadecyn-1-ol \\
\hline 16 & 15.454 & 1.00 & Heptadecanal \\
\hline 17 & 15.656 & 5.36 & Piperine \\
\hline 18 & 16.111 & 0.91 & Tricosanoic acid, methyl ester \\
\hline 19 & 16.292 & 0.80 & 7-Hexadecenal, (Z)- \\
\hline 20 & 16.445 & 1.32 & 1,2-Benzenedicarboxylic acid, butyl octyl e \\
\hline 21 & 16.601 & 1.10 & 9-Tricosene, (Z)- \\
\hline 22 & 16.643 & 1.70 & Octacosane \\
\hline 23 & 17.277 & 1.79 & n-Nonadecanol-1 \\
\hline 24 & 17.371 & 1.23 & 7-Octadecenoic acid, methyl ester \\
\hline 25 & 17.478 & 15.17 & Phytol \\
\hline 26 & 17.716 & 1.83 & 2,10-Dodecadien-1-ol,3,7,1 1-trimethyl-(Z \\
\hline 27 & 18.013 & 4.08 & Octacosane \\
\hline 28 & 18.133 & 4.12 & Piperine \\
\hline 29 & 18.425 & 3.15 & (R)-(-)-14-Methyl-8-hexadecyn-1-ol \\
\hline 30 & 19.186 & 1.27 & 1,2-Propanediol, 3-(octadecyloxy)-, diacetate \\
\hline 31 & 19.367 & 2.45 & Octacosane \\
\hline 32 & 19.773 & 8.65 & Benzene, (3-iodo-1-methoxy-1-methylpropy \\
\hline 33 & 20.326 & 0.58 & Hexadecanoic acid, 2-hydroxy-1-(hydroxym \\
\hline 34 & 20.459 & 0.69 & Di-n-octyl phthalate \\
\hline
\end{tabular}

reducing power ability. The EtOAc fractions showed good reducing power capacity which served as a significant indicator of its antioxidant activity [48].

The TAC is based on the reduction of molybdenum hexavalent oxidation state Mo (VI) to molybdenum pentavalent Mo (V) by the effect of electron donor by the antioxidant and formation of molybdenum complex colored green. The $\mathrm{TAC}$ of the fractions decreased in the order $\mathrm{BuOH}>\mathrm{Aqu}-$ eous, EtOAc $>$ DCM with the values $9.98 \pm 0.15,9.72 \pm 0.02$, $7.68 \pm 0.17 \mathrm{mg}, 6.19 \pm 0.10 \mathrm{AAE} / \mathrm{g} \pm$ SEM respectively.
The significant inhibition of $\alpha$-glucosidase and $\alpha$ amylase by $n$-butanol fraction as well as strong inhibitory effect of ethyl acetate fraction against $\alpha$-glucosidase indicates that these fractions of $80 \%$ methanol extract of $P$. guineense leaves could serve as therapeutic approach in the management of type II diabetes and some bioactive compounds in both fractions posses interesting structure-function benefits with promising potentials. Phytol, one of the major constituents in both n-butanol and ethyl acetate fractions of $P$. guineense leaves extract in the present study, has been reported to show antidiabetic and antioxidant activity in alloxan induced diabetic rats at low doses [49]. Antidiabetic activity of couramanone [50], phthalic acid and derivative of phthalate [51] present in both $P$. guineense fractions has also been reported. The antioxidant activity of $P$. guineense could be attributed to the presence of phenolic compounds [31] in $n$-butanol fraction as well as piperine and its derivatives in ethyl acetate fraction [52]. The present study corroborates the findings of Agbor et al., [53] who reported the antioxidant activity of $P$. guineense.

GCMS analysis of plant extract has been found to be one of the most powerful tools that are useful for identifying chemical constituents of plants [54]. The EtOAc and $\mathrm{BuOH}$ fractions of Piper guineense were analyzed by GC-MS to detect various compounds, a total of seventyone and thirty-four compounds were identified in $\mathrm{BuOH}$ and EtOAc fractions of Piper guineense respectively. Recent study conducted by Usman et al., [55] indicated that the component extracted from plant parts depends on the type of solvent. The major constituents of nbutanol fraction of $P$. guineense are tributyl acetylcitrate, phytol, 9, 10-Dimethyltricyclo $[4.2 .1 .1(2,5)]$ decane, 2Butenal, 2-methyl-4-(2,6,6-trimethyl-1-, 1-Cyclohexane1-methanol alpha,2,6,6, 3-Buten-2-one, 4-(4-hydroxy-2,6, 6-trimethyl, dibutyl phthalate, hexanedecanoic acid while ethyl piperonyl cyanoacetate, phytol, piperine, benzene 3-iodo-1-methoxy-1 methylpropyl, (R)-(-)-14-Methyl-8hexadecyn-1-ol, Octacosane were majorly identified in ethyl acetate fraction of $P$. guineense leaves. The activity of the fractions might be attributed to the combined action of the major compounds identified in P. guineense leaves extract.

Ojinnaka et al, [56] identified 22 peaks from the GCMS spectrum of ethanol extract of Piper guineense leaves and found that the spectrum was dominated by acids and hydrocarbon while alcohol and ester were the least constituents. The composition of 2 samples of fruit oil of $P$. guineense from Cameroon was dominated by linalool, $\beta$-caryophyllene, limonene, and $\beta$-pinene [57]. Germacrene B and limonene were the most abundant compounds of the essential oil of $P$. guineense leaves $[57,58]$. Similar components were reported in ethanol extract of $P$. guimeense leaves and seeds [16]. A sample of fruit oil of Nigerian origin contained linalool as major component 
[59]. In São Tomé, the essential oil from aerial parts mainly consists of phenyl propanoid derivatives: dillapiole and myristicine [60]. Imeh and Onyeije [61] identified 6dimethyloxazolo(5,4-c)pyridazin-4-amine, 3-(1-methylethyl)cyclohexene, 4-methoxy-N-(4-nitrobenzyl)-benzamide, alpha bisabolene, 1,2,3,4,4a,5,6,8a-octahydro-7-methyl-4-methylene1-(1-methylethyl)-napthalene, 3,7-diacetamidophenoxathin, 1, 3,3-trimethyl tricyclo\{2,2,1]heptane, 3H-indazol-3-one, $1 \mathrm{H}$ indene,octahydro-1,7a-dimethyl-4-(1-methylethenyl)-1,4methano-1H-indene, piperidine, 2,4-disopropenyl-1-methyl-1vinyl, n-hexadecanoic acid, eudesdma-4 [14],11-diene as the major components in acetone extract of $P$. guineense leaves. It is worth noting that n-butanol and ethyl acetate fractions of $80 \%$ methanol extract of $P$. guineense leaves in the present study contain constituents that are not visible with other solvents.

\section{Conclusion}

The present study investigated the antioxidant properties and antidiabetic potential of four different solvent fractions of $P$. guineense through $\alpha$-amylase, $\alpha$-glucosidase, and DPP-IV inhibitory activity. It can be inferred from the results of the study, that among the fractions, the ethyl acetate and n-butanol fractions exhibited the best antioxidant and antidiabetic potentials. Thus further investigation on the bioactive compounds eliciting these properties is imperative in search for lead compounds from natural products that could be developed into a drug for the management of diabetes mellitus. In this regard, the use of in silico approach to carry out molecular docking experiments on the compounds profiles from the two fractions against suitable molecular targets relevant in glucose metabolism can be suitable approach. Furthermore, in vitro studies using the appropriate cell lines /tissue culture investigation should also be carried out to further elucidate the probable mechanism of action of constituents of P.guineense.

\section{Acknowledgments}

None.

\section{Authors' contributions}

Sulaimon LA and Obuotor EM designed and supervised the research work. Sulaimon LA, Anise EO and Moshood Al carried out the experimental work. Anise $\mathrm{EO}$ and Olajide $\mathrm{M}$ analyzed the statistical data and interpretation of results. Sulaimon LA, Samuel TA and Fatoke T drafted and critically evaluated the manuscript. All authors read and approved the final manuscript.

\footnotetext{
Authors' information

Sulaimon LA, Moshood Al and Olajide M are lecturers/researchers at the department of Chemical Sciences (Biochemistry unit), College of Natural and Applied Sciences, Crescent University, Abeokuta, Ogun State, Nigeria. Obuotor EM is a Professor of Biochemistry and Molecular Biology at Obafemi Awolowo University, Ile-lfe, Osun State, Nigeria. Anise EO is a M.Sc. graduate of Biochemistry, Department of Chemical Sciences (Biochemistry Unit), Crescent University, Abeokuta, Ogun State, Nigeria. Samuel TA is an Associate Professor of Biochemistry at University of Lagos, Akoka, Lagos State, Nigeria. Fatoke T is a M.Sc. graduate of Biochemistry, Department of Biochemistry, University of Lagos, Lagos, Nigeria.
}

Funding

This is a self-sponsored research project.

Availability of data and materials

Data are all contained within the paper.

Ethics approval and consent to participate

This is an in vitro study that does not involve animals and human subjects. Thus ethics approval is not applicable.

Consent for publication

All authors totally agreed to the publication of the research.

\section{Competing interests}

The authors declare that they have no known competing financial interests or personal relationships that could have appeared to influence the work reported in this paper.

\section{Author details}

${ }^{1}$ Department of Chemical Sciences, College of Natural and Applied Sciences, Crescent University Abeokuta, Abeokuta, Ogun State, Nigeria. ${ }^{2}$ Department of Biochemistry, Faculty of Basic Medical Sciences, College of Medicine, University of Lagos, Lagos, Nigeria. ${ }^{3}$ Department of Biochemistry and Molecular Biology, Obafemi Awolowo University, Ile-Ife, Nigeria.

Received: 3 June 2020 Accepted: 7 December 2020

Published online: 14 December 2020

\section{References}

1. Moodley K, Joseph K, Naidoo Y, Islam S, Mackraj I. Antioxidant, antidiabetic and hypolipidemic effects of Tulbaghia violacea Harv . (Wild Garlic) Rhizome methanol extract in a diabetic rat model. BMC Complement Altern Med. 2015;15:408.

2. Eleazu CO, Iroaganachi M, Okafar PN, ljeh II, Eleazu KC. Ameliorative potential of ginger ( $Z$. officinale roscoe) on relative organ weight in Streptozotocin induced diabetic rats. Int J Biomed Sci. 2013;9(2):82-90.

3. Chen S, Tseng C. Dyslipidemia, kidney disease and cardiovascular disease in diabetic patients. Rev Diabet Stud. 2013;10:88-100.

4. International Diabetes Federation. Diabetes by Country. Brussels, Belgium: International Diabetes Federation. Diabetes Atlas. 2015; $7^{\text {th }}$ Edition. Available from www.diabetesatlas.org.

5. Mutyambizi C, Milena P, Lumbwe C, Charles H, Wim G. Cost of diabetes mellitus in Africa: a systematic review of existing literature. Glob Health. 2018;14(1):1-13.

6. Unnikrishnan R, Anjana RM, Mohan V. Diabetes mellitus and its complications. India Nat Rev Endocrinol. 2016;12:357-70.

7. Chen L, Manliano DJ, Zimmet PZ. The worldwide epidermiology of type 2 diabetes mellitus present and future perspective. Nat Rev Endocrenol. 2011; 8(4):228-36

8. Kahn SE, Cooper ME, Delprato S. Pathophysiology treatment for type 2 diabetes: prespective on past, present and future. Lancet. 2014;383(9922): 1068-83.

9. Inzucchi SE, Bergenstal RM, Buse JB, et al. Management of hyperglycemia in type 2 diabetes, a patient-centered approached: update to a position statement of the American Diabetes Association and the European association for the study of diabetes. Diabetes Care. 2015;38(1):140-9.

10. Sun J, Buys NJ. Glucose and glycemic factor lowering effect of probiotics on diabetes: a meta-analysis of randomized placebo controlled trials. $\mathrm{Br} J$ Nutr. 2016;115:1167-77.

11. Patel D, Prasad S, Kumar R, Hemalatha S. An overview on antidiabetic medicinal plants having insulin mimetic property. Asian Pac J Trop Biomed. 2010;2:320-30.

12. Babu PS, Prabuseenivasan S, Ignacimuthu S. Cinnamaldehyde-a potential antidiabetic agent. Phytomedicine. 2013;14(1):15-22.

13. Katzer and Gernot. Gernot Katzer Spice pages. 2015. http://gernot-katzersspice-pages.com/engl/Pipe_cub.html.

14. Negbenebor CA, Godiya AA, Igene JO. Evaluation of Clarias anguillains treated with spice (Piper guinnense) for washed mice and Kama book type product. Food Composit Anal. 1999;2:12-315. 
15. Igile GO, Iwara IA, Mgbaje BA, Uboh FE, Ebong PE. Phytochemical, proximate and nutrient composition of Vernonia calvaona hook (Astereceae): a green leafy vegetable in Nigeria. J Food Res. 2013;2(6):1-11.

16. Imo C, Yakubu OE, Imo NG, Udegbunam IS, Tatah SV, Onukwugha OJ. Proximate, mineral and phytochemical composition of Piper guineense seeds and leaves. J Biol Sci. 2018;18:329-37.

17. Uhegbu FO, Chinedu I, Amadike EU. Effect of aqueous extract of Piper guineense seeds on some liver enzymes, antioxidant enzymes and some hematological parameters in albino rats. Intern J. plant Sci. Ecology. 2015; 1(4):167-71.

18. Manta S, Saxena J, Nema R, Singh D, Gupta A. Phytochemistry of medicinal plants. Aust J Pharm. 2013;1(6):168-82.

19. Klin Kabari D, Barimalaa I, Achinewhu SC, Adeniji TA. Effects of extracts from 3 indigenous spices on the chemical stability of smoked dried catfish. (Clarias lazera) during storage. AJFAND. 2011;11(6):72-85

20. Chinwendu S, Ejike EN, Ejike BU, Oti WI, Nwachukwu I. Phytochemical properties of uziza leave (Piper guineense). EJPAC. 2016;3(2):12-5.

21. Gordon A, Samuel Cl, Taofik OA, Chidozie JN, Chioma OW. Biochemical effects of Piper Guineense (African Black Pepper) in female diabetics: opportunities for diabetes treatment. IJTMRPH. 2019;3(1):59-65.

22. Oyedeji OA, Adeniyi BA, Ajayi O, König WA. Essential oil composition of Piper guineense and its antimicrobial activity. Another chemotype from Nigeria. Phytother Res. 2005;19:362-4.

23. Isaac YA. Characterization and HPLC quantification of piperine in various parts of Piper guineense. In: Department of pharmaceutical chemistry. Kumasi: Kwame Nkruma University of Science and Technology; 2012.

24. Ndukwu BC, Ben-Nwadibia NB. Ethnomedicinal aspects of plants used as spices and condiments in the Niger Delta area of Nigeria. Ethnobot Leafl. 2005;1(10):1-32.

25. Madingou NOK, Souza A, Lamidi M, et al. Study of medicinal plants used in the management of cardiovascular diseases at Libreville (Gabon): an ethnopharmacological approach. Int J Pharm Sci Res. 2012;3:111-9.

26. Adegbola JD. Molluscicidal properties of some African plants. J Parasitol. 1972:107:108-15.

27. Udoh FV, Theodore $Y L$, Braide VB. Effects of extract of seed and leaf of $P$ guineense on skeletal muscles activity in rat and frog. Phytoter Res. 1999;110.

28. Ray JD. Epilepsy in China. Lancet. 1982;1024:205.

29. Sofowora A. Medicinal plant and traditional medicine in Africa. NewYork: John wiley and sons; 1982. p. 44.

30. Mba MA. Effect of dietary intake of $P$. guineense on growth and indices of fitness in Rattus rattus, Isc. Innoa. 1994;4:383-8.

31. Elizabeth EB, Morufu EB, Serges FAD, Ogochukwu SM, Jacinta NO. A review of Piper guineense (African black pepper). ljppr.Human. 2016;6(1):368-84.

32. Adefegha SA, Oboh $\mathrm{G}$. Inhibition of key enzymes linked to type 2 diabetes and sodium nitroprusside-induced lipid peroxidation in rat pancreas by water extractable phytochemicals from some tropical spices. Pharm Biol. 2012;50(7):857-65

33. Adefegha SA, Oboh G. Phytochemistry and mode of action of some tropical spices in the management of type 2 diabetes and hypertension. Afr J Pharmacol. 2013;7:332-46.

34. Iwuji SC, Nwafor A, Egwurugwu J, Ejeta K, Akpan U. Comparative characteristics of phytomedicinal constituents of Cnidoscolus aconitifolius leaf extracts. Am J. Pharm Tech. Res. 2013:3(1):779-84.

35. Akinpelu LA, Akanmu MA, Obuotor EM. Mechanism of anticonvulsant effects of ethanol leaf extract and fractions of Milicia excels (Moraceae) in mice. JPRI. 2018;23(4):1-11.

36. Wickramaratne MN, Punchihewa JC, Wickramaratne DBM. In vitro alpha amylase inhibitory activity of the leaf extracts of Adenanthera pavonina. BMC Complement Alternative Med. 2016;16:466-70.

37. Li T, Zhang XD, Song YW, Liu JW. A microplate based screening method for a-glucosidase inhibitors. J Clin Pharmacol Ther. 2005;10:1128-34.

38. Al Masari IM, Mohammed MK, Thaa MO. Inhibition of dipeptidylpeptidase IV (DPP IV) is one of the mechanisms explaining the hypoglycemic effect of Berberine. J Enzyme inhib Med Chem. 2009;24(50):1061-6.

39. Prieto $P$, Pineda M, Anguilar M. Spectrophotometric quantitation of antioxidant capacity through the formation of a phosphomolybdenum complex: specific application to the determination of vitamin E. Anal Biochem. 1999;269(2):337-41.

40. Benzie IFF, Strain JJ. The ferric reducing ability of plasma (FRAP) as a measure of antioxidant power: the FRAP assay. Anal Biochem. 1996;239(1):70-6.
41. Sulaimon LA, Adisa RA, Obuotor EM, Lawal MO, Moshood Al, Muhammad $\mathrm{NH}$. Chemical composition, antioxidant, and anticholine esterase activities of essential oil of Xylopia aethiopica seeds. Phcog Res. 2020;12:112-8.

42. Matsui T, Tanaka T, Tamura S, Toshima A, Tamaya K, Miyata Y. Alphaglucosidase inhibitory profile of catechins and theaflavins. J Agric Food Chem. 2007:55(1):99-105.

43. Green BD, Flatt PR, Bailey CJ. Inhibition of dipeptidyl peptidase IV activity as therapy of diabetes. Expert Opin Emerg Drugs. 2006;11:525-39.

44. Pathak $R$, Brideman MB. Dipeptidyl peptidase IV (DPP-IV) inhibitors in the management of diabetes. PT. 2010;35(9):509-13.

45. Nabavi SM, Ebrahimzadeh MA, Nabavi SF, Fazelian M, Eslami B. In vitro antioxidant and free radical scavenging activity of Diospyroslotus and Pyrusboissieriana growing in Iran. Pharmacognosy Mag. 2009;4(18):123-7.

46. Vadivukkarasi S, Pavithra K. Evaluation of free radical scavenging activity of various leaf extracts from Kedrostis foetidissima. Biochem Anal. 2014:10:21611009.

47. Meir S, Kanner J, Akiri B, Hader SP. Determination and involvement of aqueous reducing compounds in oxidative systems of various senescing leaves. J Agric Food Chem. 1995;43:1813-7.

48. Hazra B, Biswas S, Mandal N. Antioxidant and free radical scavenging activity of Spondias pinnata. BMC Complement Altern Med. 2008;8:63-70.

49. Arulsevan P, Gothai S, Ganesan P, Park S, Fakurazi S, Choi D. Natural phytobioactive compounds for the treatment of type 2 diabetes: inflammation as a target. Nutrients. 2016;8:461.

50. Hanbing L, Yuanfa Y, Linghuan L. Coumarins as potential antidiabetic agents. Royal Pharma. Soc. J Pharm Pharmacol. 2017;69:1253-64.

51. Sivajothi S, Shruthi SD. In vitro and In silico anti-diabetic activity of phthalic acid isolated from Phyllanthus rheedii. Int J Res Ayurveda Pharm. 2013;4(6):889-92.

52. Mittal R, Gupta RL. In vitro antioxidant activity of piperine. Methods Find Exp Clin. Pharmacol. 2000;22(5):271-4

53. Agbor GA, Vinson JA, Sortino J, Johnson R. Antioxidant and anti-atherogenic activities of three Piper species on atherogenic diet fed hamsters. Exper and Toxicol Path. 2012:64:387-91.

54. Ikpeazu OV, Otuokere IE, Igwe KK. Gas chromatography-mass spectrometric analysis of bioactive compounds present in ethanol extract of Combretum hispidum (Laws) (Combretaceae) root. Comm. in Phys. Sci. 2020;5(3):325-37.

55. Usman A, Mohammed Y, Muhammed HO, Zakari AH. Phytochemical screening and antioxidant activity of Balanites Aegyptiaca root bark extracts: influence of solvent. Comm. in Phys. Sci. 2020;5(2):152-64.

56. Ojinnaka MC, Ubbor SC, Okudu HO, Uga U. Volatile compound analysis of the leaves and seeds of Piper guineense using gas chromatography-mass spectrometry (GCMS). Afr J Food Sci. 2016;10(11):327-32.

57. Tchoumbougnang F, Jazet DPM, Sameza ML, et al. Comparative essential oils composition and insecticidal effect of different tissues of Piper capense $L$, Piper guineense Schumach and Thonn, Piper nigrum $L$ and Piper umbellatum L grown in Cameroon. Afr J Biotechnol. 2009:8:424-31.

58. Tankam JM, Ito M, Joan MT, Michiho I. Inhalation of the essential oil of Piper guineense from Cameroon shows sedative and anxiolytic-like effects in mice. Biol Pharm Bull. 2013;36(10):1608-14.

59. Owolabi MS, Lawal OA, Ogunwande IA, Hauser RM, Setzer WN. Aroma chemical composition of Piper guineense Schumach \& Thonn from Lagos, Nigeria: a new chemotype. Am J Essent Oils Nat Prod. 2013;1:37-40.

60. Martins AP, Salgueiro L, Vila R, et al. Essential oils from four Piper species. Phytochemistry. 1998;49(7):2019-23.

61. Onyeije UC, Imeh $\mathrm{O}$. Chemical information from GCSM analysis of acetone extract of Piper guineense leaves (part 1). Comm in Phys Sci. 2020;5(4):437-45.

\section{Publisher's Note}

Springer Nature remains neutral with regard to jurisdictional claims in published maps and institutional affiliations. 